\title{
H-mutant Bacteriophages as a Potential Biocontrol of Bacterial Blight of Geranium
}

\author{
J.E. Flaherty ${ }^{1}$, B.K. Harbaugh ${ }^{2}$, J.B. Jones ${ }^{3}$, and G.C. Somodi ${ }^{1}$ \\ Gulf Coast Research and Education Center, University of Florida, 5007 60th \\ Street East, Bradenton, FL 34203
}

\author{
L.E. Jackson ${ }^{4}$ \\ Agriphi Inc., P.O. Box 4296, Logan, UT 84323
}

Additional index words. Xanthomonas campestris pv. pelargonii, Pelargonium $\times$ hortorum

\begin{abstract}
Bacteriophages specific to Xanthomonas campestris pv. pelargonii (Xcp), the causal agent of bacterial blight of geranium, Pelargonium $\times$ hortorum L.H. Bailey, were isolated from soil and sludge samples from Florida, California, Minnesota, and Utah. Sixteen phages were evaluated for their potential to lyse $21 \mathrm{Xcp}$ strains collected from around the world. The $X c p$ strains varied in their susceptibility to the phage isolates with 4 to 14 phages producing a lytic or highly virulent reaction. A mixture of five h-mutants was developed from phages that exhibited the broadest host-ranges and tested against the same $X c p$ strains. The h-mutant phage mixture lysed all $21 \mathrm{Xcp}$ strains. Three experiments were designed to determine the efficacy of using a mixture of four $h$-mutant phages to control the spread of the bacterial blight pathogen on potted and seedling geraniums under greenhouse conditions. Plants surrounding diseased inoculated plants were treated with a phage mixture at $5 \times 10^{8} \mathrm{pfu} / \mathrm{mL}$ daily, biweekly, or triweekly, or treated with Phyton-27 ${ }^{\circledR}$, at $2.0 \mathrm{~mL} \cdot \mathrm{L}^{-1}$ every 10 or 14 days. In potted geraniums, daily foliar sprays of the phage mixture had reduced disease incidence and severity by $50 \%$ and $75 \%$, respectively, relative to control plants after 6 weeks. In two plug experiments, the phage mixture applied daily also had reduced disease incidence and severity by $69 \%$ and $86 \%$, and $85 \%$ and $92 \%$, respectively, when compared with controls after 5 weeks. In all three experiments, disease incidence and severity were less for plants treated daily with phages than for those treated less frequently with phages or with Phyton-27 ${ }^{\circledR}$. Chemical name used: copper sulfate pentahydrate $\left(\right.$ Phyton-27 $\left.{ }^{\circledR}\right)$.
\end{abstract}

Bacterial blight, caused by Xanthomonas campestris pv. pelargonii $(X c p)$, often is a devastating disease for growers of seedling and cutting geraniums. This disease, also referred to as bacterial stem rot, leaf spot, or bacterial wilt (Munnecke, 1954) has resulted in crop failures, especially in warmer production areas (Kivilaan and Scheffer, 1958). Once blight becomes established in a production area, chemical control measures usually prove ineffective. Proliferation of bacteria resistant to antibiotics and other bactericides, as well

Received for publication 25 May 1999. Accepted for publication 27 Apr. 2000. Florida Agricultural Experiment Station Journal Series no. R-07019. We thank the American Floral Endowment for partial funding of this research. Use of trade names does not imply endorsement of products or criticism of similar ones not mentioned. The cost of publishing this paper was defrayed in part by the payment of page charges. Under postal regulations, this paper therefore must be hereby marked advertisement solely to indicate this fact.

${ }^{1}$ Assistant In Floriculture/Plant Pathology.

${ }^{2}$ Professor of Floriculture. To whom requests for reprints should be addressed. E-mail address: brenth@nersp.nerdc.ufl.edu

${ }^{3}$ Professor of Plant Pathology. Current address: Dept. of Plant Pathology, Univ. of Florida, 1439 Fifield

Hall, Gainesville, FL 32611

${ }^{4}$ Research Scientist. as the potentially adverse effects of these chemicals on the environment, has led to renewed interest in developing alternative control strategies to combat bacterial diseases in plants.

Bacteriophages are viruses that specifically kill bacteria but are nontoxic to nontargeted beneficial bacteria and to humans. They were used as biocontrol agents as early as 1926 (Moore, 1926), and were effective in controlling Stewart's disease in corn (Zea mays L.) in 1935 (Thomas, 1935). Using phages, Civerolo and Kiel (1969) reduced bacterial spot disease of peach [Prunus persica (L.) Batsch.] seedlings caused by Xanthomonas oryzae by $86 \%$ to $100 \%$. However, use of phages was abandoned due to the emergence of bacterial mutants resistant to the single-phage types used. A method to reduce the likelihood of phage-resistant bacterial mutants emerging in a cropping system was developed by Jackson (1989). He used a mixture of different phages, including host range (h-) mutant bacteriophages. H-mutant phages, capable of attacking an extended range of bacterial isolates within a species, are spontaneously derived from their wildtype parent phages, and are so named because they lyse not only parent wild-type bacteria, but also phage-resistant mutants originating from parent bacteria. This research was con- ducted to determine: 1) if an h-mutant phage mixture could be developed that would be effective against many $X c p$ strains in vitro; and 2) the effectiveness of an h-mutant phage mixture for reducing the incidence and spread of $X c p$ on geraniums in greenhouses.

\section{Materials and Methods}

Development of a broad-spectrum bacteriophage mixture specific against Xcp. Soil, water, and sludge samples from various greenhouse production operations were screened for bacteriophages using a soft-agar technique (Billings, 1969). Sixteen phages were isolated and tested for their ability to lyse 21 $X c p$ strains collected from various geographic locations worldwide. A lysis, or death response, of the bacteria to the phage was observed as a complete clearing of bacterial cells contained in a soft-agar plate. Lysogenic reactions, where the bacteria survive an invasion by the phage, resulting in partial clearing on the soft-agar plate, were also noted. Phage isolates exhibiting the broadest host range from this test were subjected to procedures to produce h-mutants (Jackson, 1989). This laboratory procedure selects for bacteria resistant to the phages employed and then subjects these resistant bacteria to high concentrations of phages, which in turn facilitates selection of mutant phages that can attack the formerly resistant bacteria. The h-mutant phages that are produced by this procedure not only attack the resistant bacteria but also exhibit a wider intra-specific range and maintain specificity toward the wild-type bacteria.

Bacteriophage control of Xcp on potted geraniums in the greenhouse. Ten-week-old 'Pinto Red' geraniums with five to seven leaves were transplanted into $11.4 \mathrm{~cm}(0.65$ L) pots and arranged in a $3 \times 3$ array on $23-\mathrm{cm}$ centers in a greenhouse maintained at 30-32 ${ }^{\circ} \mathrm{C}$ day $/ 22-25{ }^{\circ} \mathrm{C}$ night temperatures. Plants received overhead irrigation daily. Center plants in all treatments except the noninoculated controls were inoculated by spraying plants with a five-strain combination of $X c p$ at $10^{8}$ colony-forming units (cfu) per milliliter. Silicone-polyether copolymer (Silwet surfactant, Union Carbide Corp., Canbury, Conn.) was added to the bacterial suspension to achieve a final concentration of $0.04 \%$ to promote uniform dispersal of bacterial inoculum on the plant, thereby influencing a more consistent disease progression on the inoculated plants.

The following treatments were applied to the experimental units (and center plants serving as the inoculum sources) with the initial application made $10 \mathrm{~d}$ after center-plant inoculation (to provide a window for inoculum spread): phages applied daily; phages applied biweekly; copper-based bactericide applied once every $10 \mathrm{~d}$; inoculated control; and noninoculated control. Phage and copper treatments were applied to the foliage with a compressed air sprayer ( $276 \mathrm{kPa}$ ) after morning irrigation. The phage stock mixture consisted of four h-mutants amplified to a titre of 
$10^{11}$ plaque-forming units (pfu) per milliliter. The application rate of phages used in this experiment was $5 \times 10^{8} \mathrm{pfu} / \mathrm{mL}$ or a $1: 200$ dilution of the stock solution. Phyton- $27^{\circledR}$ (Source Technology Biologicals, Minneapolis), the copper-based bactericide, was applied using the same type of sprayer at a recommended rate $\left(2.0 \mathrm{ml} \cdot \mathrm{L}^{-1}\right)$. The experimental design was a randomized complete-block with (plus the inoculated center plant). Disease incidence (percentage of plants with lesions per eight plants) and severity (number of lesions per plant) data were recorded 6 weeks after initiation of the first treatments. Statistical analyses were done by using SAS system software (SAS Institute, Cary, N.C.), and treatment means were separated by using Tukey's Studentized range (HSD) test, $P \leq 0.05$.

Bacteriophage control of Xcp on geranium seedlings. 'Maverick Red' geranium seedlings were inoculated as described above 4 weeks after sowing. Ten days later, inoculated seedlings exhibiting equivalent disease progress were randomly set into the centers four replicates of eight-plant experimental units

of modified styrofoam plug flats of either 3.5 $\mathrm{cm}\left(43-\mathrm{cm}^{3}\right.$ plugs set in a $3 \times 3$ array) or 2.5 $\mathrm{cm}\left(16-\mathrm{cm}^{3}\right.$ plugs set in a $5 \times 5$ array) square cells and healthy transplants were set into the surrounding cells. Treatments were as in the pot test, except that a third phage treatment was added in which phage was applied three times per week and the interval between Phyton- $27^{\circledR}$ applications was increased to 14 days. A randomized complete-block design was utilized with four replicates. Disease incidence was recorded as the percentage of leaves with lesions per eight $\left(3.5 \mathrm{~cm}^{2}\right)$ or 24 $\left(2.5 \mathrm{~cm}^{2}\right)$ plugs and severity as the mean number of lesions per plug 5 weeks after initiation of the first treatments. Statistical analyses were done as above.

For all experiments, the greenhouse fans were turned off during treatment application to minimize inadvertent spread of phages and the active ingredient in Phyton- $27^{\circledR}$. Irrigation occurred in the early morning and phage treatments were applied while foliage was still wet. Foliage of plants treated with Phyton- $27^{\circledast}$ was allowed to dry prior to application.

Table 1. Sensitivity ${ }^{\mathrm{z}}$ of 21 Xanthomonas campestris pv. pelargonii strains from diverse locations around the world to 16 bacteriophages isolated from California, Florida, Minnesota, and Utah.

\begin{tabular}{|c|c|c|c|c|c|c|c|c|c|c|c|c|c|c|c|c|c|}
\hline \multirow{2}{*}{$\begin{array}{l}X c p \\
\text { strains }^{y}\end{array}$} & \multicolumn{16}{|c|}{ Phage isolates } & \multirow{2}{*}{$\begin{array}{l}\text { Phage } \\
\text { mixture }\end{array}$} \\
\hline & 1 & 2 & 3 & 4 & 5 & 6 & 7 & 8 & 9 & 10 & 11 & 12 & 13 & 14 & 15 & $\overline{16}$ & \\
\hline $133 \mathrm{NZ}$ & - & - & - & - & - & - & $*$ & $*$ & * & $*$ & 0 & 0 & 0 & 0 & - & - & $*$ \\
\hline $42 \mathrm{NL}$ & $*$ & $*$ & $*$ & $*$ & $*$ & $*$ & $*$ & $*$ & $*$ & * & 0 & $*$ & $*$ & $*$ & - & $*$ & $*$ \\
\hline $46 \mathrm{NL}$ & - & - & - & - & - & $*$ & $*$ & $*$ & $*$ & $*$ & 0 & 0 & 0 & 0 & - & - & $*$ \\
\hline $47 \mathrm{NL}$ & $*$ & $*$ & $*$ & $*$ & $*$ & $*$ & 0 & 0 & 0 & $*$ & 0 & $*$ & $*$ & $*$ & - & $*$ & $*$ \\
\hline $49 \mathrm{NL}$ & $*$ & $*$ & - & - & - & - & $*$ & $*$ & * & $*$ & 0 & 0 & 0 & 0 & 0 & - & $*$ \\
\hline $50 \mathrm{NL}$ & - & - & - & $*$ & $*$ & - & $*$ & $*$ & $*$ & $*$ & 0 & 0 & - & $*$ & - & $*$ & $*$ \\
\hline $51 \mathrm{NL}$ & - & $*$ & - & - & - & $*$ & $*$ & $*$ & - & $*$ & 0 & 0 & 0 & 0 & 0 & 0 & $*$ \\
\hline $52 \mathrm{NL}$ & - & - & - & - & - & - & $*$ & $*$ & $*$ & $*$ & 0 & 0 & 0 & 0 & - & - & $*$ \\
\hline $12 \mathrm{MN}$ & - & - & - & - & 0 & $*$ & $*$ & $*$ & $*$ & $*$ & $*$ & 0 & - & 0 & - & - & $*$ \\
\hline 19FL & $*$ & - & - & - & - & $*$ & $*$ & $*$ & $*$ & $*$ & 0 & 0 & 0 & 0 & 0 & - & $*$ \\
\hline $30 \mathrm{FL}$ & - & - & $*$ & $*$ & $*$ & $*$ & 0 & 0 & 0 & - & 0 & $*$ & $*$ & $*$ & - & $*$ & $*$ \\
\hline $36 \mathrm{FL}$ & - & - & - & - & - & - & $*$ & $*$ & 0 & $*$ & 0 & 0 & - & 0 & - & - & $*$ \\
\hline 40FL & - & - & - & - & - & $*$ & $*$ & $*$ & $*$ & $*$ & 0 & 0 & 0 & 0 & - & - & $*$ \\
\hline $41 \mathrm{FL}$ & - & - & - & - & - & $*$ & * & $*$ & 0 & $*$ & 0 & 0 & - & 0 & 0 & - & $*$ \\
\hline 58FL & - & - & - & - & - & $*$ & $*$ & $*$ & $*$ & $*$ & 0 & 0 & - & $*$ & $*$ & $*$ & $*$ \\
\hline $60 \mathrm{FL}$ & - & $*$ & - & - & - & $*$ & $*$ & $*$ & $*$ & $*$ & 0 & 0 & - & 0 & - & - & $*$ \\
\hline $61 \mathrm{FL}$ & - & - & - & 0 & - & - & $*$ & $*$ & $*$ & $*$ & 0 & 0 & - & 0 & - & - & $*$ \\
\hline 74FL & - & $*$ & - & - & - & $*$ & $*$ & $*$ & $*$ & $*$ & $*$ & 0 & - & 0 & - & - & $*$ \\
\hline $8 N Y$ & - & - & $*$ & $*$ & - & $*$ & $*$ & $*$ & $*$ & $*$ & 0 & $*$ & $*$ & $*$ & - & $*$ & $*$ \\
\hline $25 \mathrm{TX}$ & - & $*$ & $*$ & $*$ & - & $*$ & $*$ & $*$ & $*$ & $*$ & $*$ & $*$ & $*$ & $*$ & - & $*$ & $*$ \\
\hline $58 \mathrm{UT}$ & $*$ & $*$ & $*$ & $*$ & $*$ & $*$ & $*$ & $*$ & $*$ & $*$ & 0 & $*$ & $*$ & $*$ & - & $*$ & $*$ \\
\hline
\end{tabular}

${ }^{2} 0=$ no reaction; - = lysogenic or nonvirulent infection; $*=$ lytic or highly virulent infection.

${ }^{\mathrm{y}} \mathrm{NZ}=$ New Zealand; NL = Netherlands; FL = Florida; NY = New York; TX = Texas; UT = Utah

\section{Results and Discussion}

Development of a broad-spectrum bacteriophage mixture specific against Xcp. The effectiveness of the different single phagetype isolates, as measured by their ability to produce a lysogenic or lytic response for each $X c p$ strain, varied considerably (Table 1). A range of 4 to 14 phage isolates produced lytic responses to each of the various $X c p$ strains tested. Five phages (phage isolates $6,7,8,9$, and 10) were extremely effective, producing lytic reactions on 15 to 21 of the $X c p$ strains (Table 1). While many phage isolates produced lysogenic responses on many $X c p$ strains, these reactions were not considered strong enough for those phages to be used in subsequent h-mutant selection procedures.

Phage isolates 6 to 10 were subjected to procedures to produce h-mutants as described in the materials and methods, and five hmutants were isolated and used to test the effectiveness of an h-mutant phage mixture. The h-mutant phage mixture produced a lytic response for all $21 \mathrm{Xcp}$ strains (last column, Table 1). These results indicate that this novel bacteriophage technique was adaptable for development of an h-mutant phage mixture that was effective against a wide range of $X c p$ strains.

Bacteriophage control of Xcp on potted geraniums in the greenhouse. Daily phage applications resulted in a reduction in incidence from $53 \%$ (inoculated control) to $<20 \%$ (Table 2). Phages applied less frequently (twice weekly) failed to provide significant differences in disease incidence or severity compared with the inoculated controls. Similarly, applications of Phyton- $27^{\circledR}$ did not significantly reduce disease incidence or severity relative to inoculated controls.

Bacteriophage control of Xcp on geranium seedlings. Incidence of $X c p$ on the inoculated controls ranged from $13 \%\left(2.5-\mathrm{cm}^{2}\right.$ plugs, Table 3 ) to $16 \%\left(3.5-\mathrm{cm}^{2}\right.$ plugs), while incidence on plants treated daily with phages ranged from $1.9 \%\left(2.5-\mathrm{cm}^{2}\right.$ plugs $)$ to $5.4 \%$ $\left(3.5-\mathrm{cm}^{2}\right.$ plugs). Phages applied less frequently (twice weekly) failed to reduce disease incidence significantly. However, a significantly lower disease severity was noted in the $2.5-\mathrm{cm}^{2}$ plug experiment, where less
Table 2. Effect of bacteriophages specific to Xanthomonas campestris pv. pelargonii on incidence and severity of bacterial blight on potted $(0.65 \mathrm{~L})$ geraniums after 6 weeks.

\begin{tabular}{lcc}
\hline Treatment $^{\mathrm{z}}$ & Incidence $^{\mathrm{y}}$ & Severity $^{\mathrm{x}}$ \\
\hline Phage applied daily & $19 \mathrm{a}^{\mathrm{w}}$ & $1.8 \mathrm{a}$ \\
Phage applied $2 \times / \mathrm{wk}$ & $50 \mathrm{~b}$ & $9.4 \mathrm{~b}$ \\
Phyton- $27^{\circledR} 1 \times / 10 \mathrm{~d}$ & $53 \mathrm{~b}$ & $9.5 \mathrm{~b}$ \\
Inoculated conrol & $53 \mathrm{~b}$ & $7.6 \mathrm{~b}$ \\
Healthy control & $6 \mathrm{a}$ & $0.6 \mathrm{a}$ \\
\hline${ }^{2}$ The phage mixture was applied at a rate of $5 \times 10^{8}$ \\
pfu/mL and Phyton- $27^{\circledR}$ at $2.0 \mathrm{~mL} \cdot \mathrm{L}^{-1}$. \\
y Incidence = percentage of plants exhibiting lesions \\
per eight-plant experimental unit. \\
xSeverity = mean number of lesions per plant. \\
"Mean separation within columns by Tukey's \\
Studentized range (HSD) test, $P \leq 0.05$.
\end{tabular}

Table 3. Effect of bacteriophages specific to Xanthomonas campestris pv. pelargonii on incidence and severity of bacterial blight on geranium seedlings after 5 weeks. Geraniums were contained in plug trays with either a $2.5-\mathrm{cm}^{2}$ plug size arranged in a $5 \times 5$ array or $3.5-\mathrm{cm}^{2}$ plug size arranged in a $3 \times 3$ array.

\begin{tabular}{|c|c|c|c|c|}
\hline \multirow[b]{2}{*}{ Treatment $^{\mathrm{z}}$} & \multicolumn{2}{|c|}{$2.5-\mathrm{cm}^{2}$ plugs } & \multicolumn{2}{|c|}{$3.5-\mathrm{cm}^{2}$ plugs } \\
\hline & Incidence $^{\mathrm{y}}$ & Severity $^{x}$ & Incidence & Severity \\
\hline Phage applied daily & $2 a^{w}$ & $1.1 \mathrm{ab}$ & $5 \mathrm{a}$ & $1.1 \mathrm{ab}$ \\
\hline Phage applied $2 \times /$ wk & $8 \mathrm{~b}$ & $2.4 \mathrm{~b}$ & $13 \mathrm{~b}$ & $2.9 \mathrm{bc}$ \\
\hline Phage applied $3 \times /$ wk & $4 \mathrm{ab}$ & $3.1 \mathrm{~b}$ & $13 \mathrm{~b}$ & $4.9 \mathrm{bc}$ \\
\hline Phyton- $27^{\circledR} 1 \times / 2$ wk & $13 \mathrm{~b}$ & $9.7 \mathrm{c}$ & $23 \mathrm{c}$ & $10.8 \mathrm{c}$ \\
\hline Inoculated control & $13 \mathrm{~b}$ & $15.2 \mathrm{c}$ & $16 \mathrm{~b}$ & $7.9 \mathrm{c}$ \\
\hline Healthy control & $0 \mathrm{a}$ & $0.0 \mathrm{a}$ & $0 \mathrm{a}$ & $0.0 \mathrm{a}$ \\
\hline
\end{tabular}

${ }^{2}$ The phage mixture was applied at a rate of $5 \times 10^{8} \mathrm{pfu} / \mathrm{mL}$ and Phyton- $27^{\circledR}$ at 2.0 $\mathrm{mL} \cdot \mathrm{L}^{-1}$.

${ }^{\mathrm{y}}$ Incidence $=$ percentage of leaves with lesions per $24\left(2.5 \mathrm{~cm}^{2}\right)$ or eight $\left(3.5 \mathrm{~cm}^{2}\right)$ plugs.

${ }^{\mathrm{x}}$ Severity $=$ the mean number of lesions per plug.

wMean separation within columns by Tukey's Studentized range (HSD) test, $P \leq 0.05$. 
frequent phage applications reduced lesions up to $75 \%$ compared with the controls (Table 3 ). There were no significant differences between plants receiving Phyton- $27^{\circledR}$ and the inoculated controls in either plug tray experiments after 5 weeks.

Results from these tests utilizing an h-mutant phage mixture in a greenhouse production environment indicate that phages may be most effective as a biological control of bacterial blight on geranium when applied daily. In preliminary studies, we have noted that phage longevity on the leaf surface decreases significantly after $24 \mathrm{~h}$, thus reducing the efficacy of less frequent applications. Recognizing that daily applications may not be economically feasible, we are currently evaluating compounds that extend the longevity of phages in the cropping environment.

\section{Literature Cited}

Billings, E. 1969. Isolation, growth and preservation of bacteriophages, p. 315-329. In: J.R. Norris and D.W. Robbins (eds.). Methods in microbiology. Academic, London.

Civerolo, E.L. and H.L. Kiel. 1969. Inhibition of bacterial spot of peach foliage by Xanthomonas pruni bacteriophage. Phytopathology
59:1966-1967.

Jackson, L.E. 1989. Bacteriophage prevention and control of harmful plant bacteria. U.S. Patent No. 4,828,999.

Kivilaan, A. and R.P. Scheffer. 1958. Factors affecting development of bacterial stem rot of Pelargonium. Phytopathology 48:185-191.

Moore, E.S. 1926. D'Herelle's bacteriophage in relation to plant parasites. South Afr. J. Sci. 23:306.

Munnecke, E. 1954. Bacterial stem rot and leaf spot of Pelargonium. Phytopathology 33:626-632.

Thomas, R.C. 1935. A bacteriophage in relation to Stewart's disease of corn. Phytopathology 25:371-372. 